\title{
MENCIPTAKAN MILENIAL ENTREPRENEUR MELALUI PEMBELAJARAN KEWIRAUSAHAAN SOSIAL PADA MAHASISWA
}

\author{
Oleh: \\ Nazlah Rachma Panggabean ${ }^{1)}$ \\ Dearma Sariani Sinaga ${ }^{2)}$ \\ Universitas Darma Agung, Medan 1,2) \\ E-mail: \\ nazla89gabe@gmail.com ${ }^{1)}$ \\ dearmasinaga2@gmail.com $^{2)}$
}

\begin{abstract}
Several problems are found in the field of students 'low understanding of social entrepreneurship, lack of students' skills in social entrepreneurship and low motivation to become entrepreneurial. This research was conducted at Darma Agung University which is engaged in education where the vision of Darma Agung University is to become a leading and character-based university entrepreneurship in 2035, therefore it must be supported by students' understanding of entrepreneurship learning with social entrepreneurship specifications. The goal is to create young entrepreneurs through social entrepreneurship courses among students. With the growth of entrepreneurs among students, it means not only growing the economy but also aiming at increasing the ability of local communities to utilize the resources owned by Indonesia in general, and the areas where they live in particular. Apart from being capable young entrepreneurs, of course this nation also needs entrepreneurs who have empathy or have social skills. Entrepreneurs can also move in the social field. In addition to being a young generation who is financially successful, the nation's young generation is also expected to have social concern for the surrounding environment. This study using path analysis method (path analysis) is a method to determine the effect of each variable to be studied. In this study there are 2 independent variables, namely interest and ability, then the dependent variable is social entrepreneurship learning and the intermediate variable is the millineal entrepreneur. From the results of data processing the effect of interest, the ability to learn social entrepreneurship is $74.4 \%$ while the remaining $25.6 \%$ is influenced by other factors that are not researched. Meanwhile, the influence of interest, ability and social entrepreneurship learning on millineal entrepreneur is $23.3 \%$, while the remaining $76.7 \%$ is influenced by other factors that are not examined.
\end{abstract}


Keywords: Young Entrepreneurs, Social Entrepreneurs

\begin{abstract}
ABSTRAK
Ada beberapa masalah ditemukan di lapangan rendahnya pemahaman mahasiswa tentang kewirausahaan social, belum terasanya keterampilan mahaiswa dalam kewirausahaan social dan rendahnya motivasi untuk menjadi kewirausahaan Penelitian ini dilakukan di Universitas Darma Agung yang bergerak dibidang pendidikan dimana visi Universitas Darma Agung adalah menjadi universitas terkemuka dan berkarakter yang berbasis entrepreneurship Tahun 2035, maka dari itu harus didukung dengan pemahaman mahasiswa tentang pembelajaran kewirausahaan dengan spesifikasi kewirausahaan sosial. Tujuan untuk menciptakan para entrepreneur muda melalui kuliah kewirausahaan sosial dikalanganan mahasiswa. Dengan tumbuhnya para wirausahawan dikalangan mahasiswa, artinya bukan hanya menumbuhkan perekonomian tetapi juga bertujuan untuk meningkatkan kemampuan masyarakat lokal dalam memanfaatkan sumber daya yang dimiliki Indonesia umumnya, dan daerah tempat tinggal mereka khususnya. Selain menjadi wirausahaan muda yang cakap, tentunya bangsa ini juga membutuhkan wirausahwan yang berempati atau memiliki kecakapan sosial. Wirausaha dapat bergerak dalam bidang sosial pula. Selain menjadi generasi muda yang sukses secara finansial, generasi muda bangsa juga diharapkan memiliki kepedulian sosial terhadap lingkungan sekitarnya. Dalam penelitian ini menggunakan metode analisis jalur (path analysis) merupakan metode untuk mengetahui pengaruh dari setiap variabel yang akan diteliti. Pada penelitian ini terdapat 2 variabel bebas adalah minat dan kemampuan selanjutnya variabel terikat adalah pembelajaran kewirausahaan sosial dan variabel antara adalah milineal entrepreneurDari hasil pengolahan data pengaruh minat, kemampuan terhadap pembelajaran kewirausahaan sosial sebesar 74,4\% sedangkan sisanya sebesar $25,6 \%$ dipengaruhi oleh faktor lain yang tidak diteliti. Sedangkan pengaruh minat, kemampuan dan pembelajaran kewirausahaan sosial terhadap milineal entrepreneur sebesar $23,3 \%$ sedangkan sisanya sebesar 76,7\% dipengaruhi faktor lain yang tidak diteliti.
\end{abstract}

Kata kunci: Entrepreneur muda, Wirausaha Sosial, Wirausahawan Sosial

PENDAHULUAN

Kewirausahaan berperan penting bagi kegiatan ekonomi di Negara berkembang, wirausaha bias menjadi mesin pendorong perekonomian dan juga menciptakan lapangan kerja. Tingginya tingkat persaingan dalam dunia kerja menuntut masyarakat Indonesia untuk memiliki sejumlah kemampuan dan keterampilan yang tinggi agar mampu bersaingan untuk mendapatkan pekerjaan. Kewirausahaan social menjadi salah satu konsep global alternative untuk mengkaji aktivitas dengan memiliki 
tujuan yang tidak hanya ekonomi semata-mata, akan tetapi juga dapat mencakup kajian social dan lingkungan. Kewirausahaan social sedang mengalami peningkatan dimasa saat ini. Karenakan mampu mengatasi kegagalan pasar dan kegagalan pemerintah dalam bidang pengembangan ekonomi dibidang kewirausahaan. Di negara dengan pendapatan menengah kebawah, kegagalan pasar dan kegagalan pemerintah sering sekali ditemukan. Karena itu, sebuah pemikiran baru seperti kewirausahaan sosial, sangat diperlukan untuk menganalisis secara mendalam aktivitas ekonomi, khususnya organisasi nirlaba dan koperasi.

Pembelajaran kewirausahaan memberikan ketrampilan khusus pada anak didik, sehingga dapat mengelola ketrampilannya sebagai sumber penghidupannya dan dapat membantu masyarakat dilingkungan tempat tinggalnya. Disini peranan pembelajaran kewirausahaan dalam implementasi ketrampilan, sehingga anak didik mampu bertahan dengan kemampuan mengelola ketrampilan dirinya.

\section{TINJAUAN PUSTAKA}

\section{Pengertian}

\section{Kewirausahaan Sosial}

Germak \& Singh menyatakan bahwa kewirausahaan sosial mengkkombinasikan ide-ide inovatif untuk perubahan sosial yang dilakukan dengan mengaplikasikan strategi dan keterampilan bisnis. Kewirausahaan sosial merupakan gabungan dari konsep-konsep tersebut. Kewirausahaan sosial dilakukan dengan cara memberdayakan masyarakat untuk meningkatkan kesejahteraan melalui pemanfaatan sumber daya yang mereka miliki dengan melakukan inovasi.

\section{Pengertian Millennial}

Istilah millennial yang diciptakan oleh dua pakar sejarah dan penulis Amerika, William Strauss dan Neil Howe dalam beberapa bukunya. Millennial pada umumny adalah anak-anak dari generasi Baby Boomers dan Gen-X yang tua. Milenial kadang-kadang disebut sebagai "Echo Boomers" karena adanya "booming" (peningkatan besar), tingkat 
kelahiran pada tahun 1980-an dan 1990-an. Para pakar menggolongkannya berdasarkan tahun awal dan akhir. Penggolongan generasi $\mathrm{Y}$ terbentuk bagi mereka yang lahir pada 1980-1990, atau pada awal 2000, dan seterusnya.

\section{Pengertian Minat}

Zulianto (2014) menyebutkan bahwa minat berwirausaha dalam banyak penelitian dikenal dengan beberapa istilah yaitu motivasi berwirausaha, niat berwirausaha dan intensi kewirausahaan. Urban dkk (Zulianto dkk, 2014) menyebutkan bahwa istilah intensi berwirausaha merupakan istilah yang memiliki kedekatan dengan istilah lain yang sering digunakan dengan arti yang sama, misalnya kesadaran kewirausahaan, potensi kewirausahaan, calon pengusaha, kecenderungan.

\section{Pengertian Kemampuan}

Kemampuan berasal dari kata mampu yang berarti (bisa, sanggup) melakukan sesuatu, sedangkan kemampuan berarti kesanggupan, kecakapan. Kemampuan (ability) berarti kapasitas seseorang individu untuk melakukan beragam tugas dalam suatu pekerjaan (Stephen P. Robbins \& Timothy A Judge, 2010). Sementara itu, menurut Robbins (2008:57) kemampuan berarti kapasitas seseorang individu untuk melakukan beragam tugas dalam suatu pekerjaan.

\section{METODE PELAKSANAAN}

\section{Uji Hipotesis}

Langkah selanjutnya adalah teknik pengujian hipotesis yang digunakan untuk mengetahui apakah terdapat pengaruh yang signifikan dari variable bebas terhadap variable terikat dengan Uji Statistik F dan Uji Statistik t.

a. Uji Signifikan Parameter Individual (UjiStatistik t) Pengambilan keputusan pada uji statistik t dapat dilakukan dengan melihat signifikannya pada taraf kepercayaan 0,05 dengan kriteria :

1. Jika thitung $>$ tabel maka hipotesis diterima.

2. Jika thitung $<t_{\text {tabel }}$ maka hipotesis ditolak.

b. Uji Signifikan Simultan (Uji Statistik F)

Pengambilan keputusan pada 
uji statistik F dapat dilakukan dengan melihat signifikannya pada taraf kepercayaan 0,05 dengan kriteria :

1. Jika $F_{\text {hitung }}>F_{\text {tabel }}$ maka hipotesis diterima.

2. Jika $F_{\text {hitung }}<\mathrm{F}_{\text {tabel }}$ maka hipotesis ditolak.

\section{Koefisien Determinasi $\left(\mathbf{R}^{2}\right)$}

Koefisien determinasi bertujuan untuk mengukur seberapa jauh kemampuan model dalam menerangkan variasi variable dependen (Ghozali, 2012:97). Nilai koefisien determinasi adalah antara nol dan satu. Nilai $\mathrm{R}^{2}$ yang kecil berarti kemampuan variabel-variabel independen dalam menjelaskan variasi variable depen den amat terbatas.

\section{Analisis Jalur (Path}

\section{Analysis)}

Menurut Kuncoro (2014) model analisis jalur digunakan untuk menganalisis pola hubungan antar variabel dengan tujuan untuk mengetahui pengaruh langsung maupun tidak langsung seperangkat variabel independen (eksogen) terhadap variabel dependen (endogen).

\section{HASIL DAN PEMBAHASAN}

\section{Profil Responden}

Responden dalam penelitian ini adalah mahasiswa fakultas hukum Univesitas Darma Agung. Dalam penelitian ini, peneliti mengelompokan profil responden berdasarkan jenis kelamina dan tahun kelahiran. Berikut ini hasil pengelompokan profil responden :

\section{a. Jenis Kelamin}

Dalam penelitian ini, total responden berjumlah 70 orang responden, dimana sebanyak 64 orang pria $(91,4 \%)$ dan $6(8,6 \%)$ orang wanita.

\section{b. Tahun Lahir Responden}

Total responden bejumlah 70 orang responden, diperoleh responden yang diman tahun kelahiran 1980-an sebanyak 2 orang $(2,9 \%)$, tahun kelahiran 1990-an sebanyak 57 orang $(81,4 \%)$ dan tahun kelahiran 2000-an sebanyak 11 orang $(15,7 \%)$.

\section{Uji Hipotesis}




\section{Coefficients $^{\mathrm{a}}$}

\begin{tabular}{|c|c|c|c|c|c|c|}
\hline \multirow[b]{2}{*}{ Model } & & \multicolumn{2}{|c|}{ Unstandardized Coefficients } & \multirow{2}{*}{$\begin{array}{l}\text { Standardized } \\
\text { Coefficients } \\
\text { Beta }\end{array}$} & \multirow[b]{2}{*}{$\mathrm{t}$} & \multirow[b]{2}{*}{ Sig. } \\
\hline & & $\mathrm{B}$ & Std. Error & & & \\
\hline \multirow[t]{3}{*}{1} & (Constant) & -.145 & .132 & & -1.105 & .273 \\
\hline & TRANSFORM_X1 & .286 & .089 & .313 & 3.222 & .002 \\
\hline & TRANSFORM_X2 & .530 & .086 & .598 & 6.159 & .000 \\
\hline
\end{tabular}

a. Dependent Variable: TRANSFORM_Y

Dari tabel di atas, dapat dijelaskan pengaruh masing-masing variabel bebas terhadap variabel terikat sebagai berikut :

$$
\mathrm{Y}=\mathbf{- 0 , 1 4 5}+\mathbf{0 , 2 8 6}+\mathbf{0 , 5 3 0}+\mathrm{e} 1
$$

1. Nilai kostanta adalah $-0,145$ artinya jika faktor minat dan kemampuan sama dengan nol maka nilai pembelajaran kewirausahaan sosial sebesar $-0,145$.

2. Koefisien regresi untuk minat sebesar 0,110 artinya bahwa setiap kenaikan $1 \%$ faktor minat maka pembelajarna kewirausahaan sosial akan mengalami peningkatan sebesar 0,110

3. Koefisien regresi untuk kemampuan sebesar 0,530 artinya bahwa setiap kenaikan $\quad 1 \% \quad$ faktor kemampuan maka pembelajaran kewirausahaan sosial akan mengalami peningkatan.

\section{2) Hasil Uji - t Regresi Linier}

\section{Model 2}

\section{Coefficients ${ }^{\mathrm{a}}$}

\begin{tabular}{|c|c|c|c|c|c|c|}
\hline \multirow[b]{2}{*}{ Model } & & \multicolumn{2}{|c|}{ Unstandardized Coefficients } & \multirow{2}{*}{$\begin{array}{c}\text { Standardized } \\
\text { Coefficients } \\
\text { Beta }\end{array}$} & \multirow[b]{2}{*}{$\mathrm{t}$} & \multirow[b]{2}{*}{ Sig. } \\
\hline & & B & Std. Error & & & \\
\hline 1 & (Constant) & 1.933 & .200 & & 9.664 & .000 \\
\hline & TRANSFORM_X1 & .225 & .144 & .284 & 1.561 & .123 \\
\hline
\end{tabular}




\begin{tabular}{lr|r|r|r|r|r}
\hline TRANSFORM_X2 & -.029 & .162 & -.037 & -.176 & .861 \\
\hline TRANSFORM_Y & .226 & .184 & .262 & 1.230 & .223 \\
\hline
\end{tabular}

a. Dependent Variable: TRANSFORM_Z

Dari tabel di atas, dapat dijelaskan pengaruh masing-masing variabel bebas terhadap variabel terikat sebagai berikut :

\section{$Z=1,933+0,225 x_{1}-0,029 x_{2}+0,226$}

1. Nilai kostanta adalah 1,933 artinya jika faktor minat dan kemampuan sama dengan nol maka nilai pembelajaran kewirausahaan sosial sebesar 1,933 .

2. Koefisien regresi untuk minat sebesar 0,225 artinya bahwa setiap kenaikan $1 \%$ faktor minat maka millineal entrepreneur akan mengalami peningkatan sebesar 0,225.
3. Koefisien regresi untuk kemampuan sebesar 0,029 artinya bahwa setiap kenaikan $\quad 1 \%$ faktor kemampuan, maka millineal entrepreneur akan mengalami peningkatan sebesar 0,029

4. Koefisien regresi untuk pembelajaran kewirausahaan sosial sebesar 0,226 artinya bahwa setiap kenaikan $1 \%$ faktor kemampuan maka millineal entrepreneur akan mengalami peningkatan sebesar 0,226

a. Hasil Uji - F Regresi Linier Model 2

ANOVA $^{\mathrm{a}}$

\begin{tabular}{llr|r|r|r|r} 
Model & Sum of Squares & df & Mean Square & F & Sig. \\
\hline 1 & Regression & 106.031 & 2 & 53.016 & 97.372 & $.000^{\mathrm{b}}$ \\
\cline { 2 - 5 } & Residual & 36.479 & 67 & .544 & \\
\hline Total & 142.510 & 69 & & \\
\end{tabular}

a. Dependent Variable: TRANSFORM_Y

b. Predictors: (Constant), TRANSFORM_X2, TRANSFORM_X1

Pada table di atasdapat sebesar 0,000. Karena nilai diketahui bahwa diperoleh nilai $\mathrm{F}$ signifikansinya rendah yakni lebih sebesar 97,372 dan nilai signifikansi kecil dari $0,05(\alpha=0,05)$ maka 
hipotesis diterima. Dengan demikian model regresi antara minat, kemampuan terhadap pembelajaran kewrausahaan sosial dinyatakan fit atau layak.

\section{b. Hasil uji - F Regresi Linier} Model 2

ANOVA $^{\mathrm{a}}$

\begin{tabular}{|c|c|c|c|c|c|c|}
\hline \multicolumn{2}{|c|}{ Model } & Sum of Squares & df & Mean Square & $\mathrm{F}$ & Sig. \\
\hline \multirow[t]{3}{*}{1} & Regression & 24.797 & 3 & 8.266 & 6.690 & $.001^{\mathrm{b}}$ \\
\hline & Residual & 81.549 & 66 & 1.236 & & \\
\hline & Total & 106.346 & 69 & & & \\
\hline
\end{tabular}

Dapat diketahui bahwa diperoleh nilai F sebesar 6.690 dan nilai signifikansi sebesar 0,001 . Karena nilai signifikansinya rendah yakni lebih kecil dari 0,05 $(\alpha=0,05)$ maka hipotesis diterima. Dengan demikian model regresi antara minat, kemampuan dan pembelajaran kewrausahaan terhadap Milineal Entrepreneur dinyatakan fit atau layak.

\section{Koefesien Determinasi}

\section{Determinasi Regresi Linier Model 1}

\begin{tabular}{|c|c|c|c|c|}
\hline \multicolumn{5}{|c|}{ Model Summary } \\
\hline Model & $\mathrm{R}$ & R Square & $\begin{array}{c}\text { Adjusted R } \\
\text { Square }\end{array}$ & $\begin{array}{c}\text { Std. Error of the } \\
\text { Estimate }\end{array}$ \\
\hline 1 & $.863^{\mathrm{a}}$ & .744 & .736 & .73788 \\
\hline
\end{tabular}

Nilai R Square sebesar 0,744, artinya adalah sumbangan pengaruh Minat $\mathrm{X}_{1}$ dan Kemampuan $\quad\left(\mathrm{X}_{2}\right)$ terhadap Pembelajaran Kewirausahaan Sosial (Y) sebesar 74,4\%, sedangkan sisanya sebesar 25,6 $\%(100 \%$ - 74,4\%) dipengaruhi oleh faktor lain yang tidak diteliti.

2. Determinasi Regresi Linier Model 2 


\begin{tabular}{|c|c|c|c|c|}
\hline \multicolumn{5}{|c|}{ Model Summary } \\
\hline Model & $\mathrm{R}$ & R Square & $\begin{array}{l}\text { Adjusted R } \\
\text { Square }\end{array}$ & $\begin{array}{l}\text { Std. Error of the } \\
\text { Estimate }\end{array}$ \\
\hline 1 & $.483^{\mathrm{a}}$ & .233 & .198 & 1.11157 \\
\hline
\end{tabular}

Nilai R Square sebesar 0,233 artinya adalah sumbangan Minat (X1), Kemampuan (X2), dan Pembelajaran Kewirausahaan Sosial (Y) mampu menjelaskan variabel Milineal Entrepreneur (Z) sebesar $\quad 25,3 \%$ semantara sisanya sebesar $76,7 \%(100 \%$ $25,3 \%$ ) dipengaruhi oleh faktor lain yang tidak diteliti.

\section{Analisis Jalur}

Dari analiss regresi satu dan regresi dua diperoleh analisis jalur sebagai berikut:

\section{Pengaruh Langsung Dan Tidak Langsung}

Pada model jalur, penelitian ini akan menjelaskan pengaruh langsung dan tidak langsung variabel .

\section{a. Pengaruh Minat terhadap Milineal Entrepreneur \\ $>$ Pengaruh Langsung}

Dari hasil perhitungan yang didapat menunjukan bahwa nilai pengaruh langsung minat terhadap
Milineal Entrepreneur 0,284 lebih besar dari nilai pengaruh tidak langsung minat terhadap Milineal Entrepreneur 0,082

$>$ Pengaruh Tidak Langsung (Melalui Pembelajaran

\section{Kewirausahaan Sosial)}

Sementara pengaruh tidak langsung minat terhadap Pembelajaran Kewirausahaan Sosial sebesar $0.313 \times 0.262=$ 0.082. maka pengaruh total yang 
diberikan minat terhadap milinal adalah $0,284+0,082=0,366$. Dengan hasil ini maka dapat disimpulakan bahwa artinya secara tidak langsung minat melalui pembelajaran kewirausahaan sosial pada mahasiswa tidak berpengaruh signifikan terhadap Milineal Entrepreneur.

\section{b. Pengaruh Kemampuan Terhadap Milineal Entrepreneur}

\section{$>$ Pengaruh Langsung}

Hasil penelitian ini memperlihatkan pengaruh langsung kemampuan terhadap Milineal Entrepreneur sebesar 0,037 lebih kecil dari nilai pengaruh tidak langsung kemampuan terhadap Milineal Entrepreneur 0,157.

\section{Pengaruh Tidak Langsung} (Melalui Pembelajaran

\section{Kewirausahaan Sosial)}

Sementara pengaruh tidak langsung kemampuan melalui Pembelajaran Kewirausahaan Sosial terhadap Milineal Entrepreneur sebesar $0,598 \quad \mathrm{x}$ $0,262=0,157$. Maka pengaruh total yang diberiakn kemampuan terhadap Milineal Entrepreneur = $-0,037+0,157=0,12$. Dari hasil perhitungan didapat menunjukan bahwa nilai pengaruh langsung kemampuan terhadap Milineal Entrepreneur sebesar -0,037 lebih kecil dari nilai pengaruh tidak langsung terhadap Milineal Entrepreneur sebesar 0,157, maka artinya secara tidak langsung kemampuan melalui pembelajaran kewirausahaan sosial berpengaruh signifikan terhadap Milineal Entrepreneur

\section{Pembahasan}

1. Pengaruh Minat terhadap Pembelajaran Kewirausahaan Sosial

Hasil penelitian ini menyatakan bahwa variabel minat berpengaruh positif dan signifikan terhadap variabel pembelajaran kewirausahaan sosial. Berdasarkan hasil pengujian regresi menunjukan bahwa $t_{\text {hitung } 3,222}>\mathrm{t}_{\text {tabel }} 1,666$ dari hasil deskriptif variabel menghasilkan bahwa sebagin besar respondeng/mahasiswa memandang penting variabel minat sebagai faktor yang dapat meningkatkan pemahaman terhadap variabel pembelajaran kewirausahaan sosial. Disamping itu sebagai besar responden/mahasiswa menyatakan 
pembelajaran Kewirausahan Sosial sangat berguna karena mahasiswa/responden akan memahami bahwa banyak jenis dalam kewirausahaan, salah satunya wirausahaan sosial.

Berdasarkan data tersebut diatas menunjukan bahwa minat merupakan salah satu penentu pembelajaran kewirausahaan sosial berjalan dengan baik karena apabila seseorang memiliki minat maka pembelajaran kewirausahaan sosial akan berjalan dengan lancar.Hasil penelitian ini menunjukan bahwa adanya hubungan pendidikan kewirausahaan sosialdengan peningkatkan minat minat mahasiswa dalam wirausaha.

\section{Pengaruh Kemampuan terhadap Pembelajaran Kewirausahaan Sosial}

Hasil penelitian in
menyatakan bahwa variabe kemampuan berpengaruh positif dan signifikan terhadap variabel pembelajaran kewirausahaan sosial. Berdasarkan hasil pengujian regresi menunjukan bahwa thitung 6,159> tabel1,666 dari hasil deskriptif variabel menghasilkan bahwa sebagin besar respondeng/mahasiswa memandang penting variabel kemampuan sebagai faktor yang dapat meningkatkan pemahaman terhadap variabel pembelajaran kewirausahaan sosial.
Berdasarkan hal tersebut di atas dapat diketahui bahwa mahasiswa perlu mengembangkan ide-ide dan gagasan dalam berwirausaha untuk menghasilkan kemampuan. Dengan mendapatkan pembelajaran kewirausahaan sosial akan membentuk pola pikir mahasiswa terhadap wirausaha untuk menghasilkan nilai dari kegiatan wirausaha tersebut.

\section{Pengaruh Minat terhadap Milineal Entrepreneur}

Berdasarkan hasil penelitian menunjukan bahwa minat tidak berpengaruh secara langsung terhadap mileneal entrepreneur dikalangan mahasiswa difakultas hukum. Hal ini disebabkan nilai sig. lebih besar dari taraf signifikansi yang ditentukan. Dari data yang dapat diketahuai bahwa minat untuk berwirausahan pada generasi milenial tidak ada karena responden/mahasiswa di fakultas hukum menjelaskan bahwa mereka lebih berminat untuk menjadi aparat penegak hukum yang handal seperti Kepolisian Negara Repoblik Indonesia, Mahkamah Konstitusi, Mahkamah Agung, Pengadilan Militer, ketika mereka belum mendapatkan pendidikan kewirausahaan khususnya kewirausahaan sosial.

Setelah mendapatkan pendidikan kewirausahaanmahasiswa mendapatakan pemahaman tentang 
berbagai jenis peran atau karir yang ada di dalam matakuliah kewirausahaan salah satunya adalah kewirausahaan sosial dimana karir ini masyarakat atau lingkungan mereka dapat terbantu. Hasil ini menunjukan bahwa aspek dorongan dari dalam maupun luar individu memberikan pengaruh terhadap kecendrungan generasi melenial untuk berwirausahan.

\section{Pengaruh Kemampuan terhadap \\ Milineal \\ Entrepreneur}

Berdasarkan hasil penelitian menunjukan bahwa kemampuan tidak berpengaruh secara langsung terhadap mileneal entrepreneur dikalangan mahasiswa difakultas hukum. Hal ini disebabkan nilai sig. lebih besar dari taraf signifikansi yang ditentukan. Millineal entrepreneur ditimbulkan dari diri seseorang meliputi faktor internal dan external. Faktor internal adalah bakat sedangkan faktor external adalah lingkungan. Dari beberapa faktor internal yang ditimbulakan diri seseorang dan dikembangkan melalui sebuah proses pembelajaran menuju millineal entrepreneuar.

\section{Minat}

melalui

Pembelajaran

Kewirausahaan terhadap

Milineal

\section{Entrepreneur}

Milineal entrepreneuer dalam model penelitian ini tidak memediasi hubungan antara minat terhadap milineal entrepreneur. Variabel pembelajaran kewirausahaan sosial pada mahasiswa tidak mengakibatkan variabel minat mempengaruhi variabel milineal entrepreneur secara tidak langsung. Hal ini ditunjukan dari nilai pengaruh tidak langsung varaibel minat terhadap milineal entrepreneur melalui pembelajaran kewirausahaan sosial pada mahasiswa nilainya lebih kecil dari nilai pengaruh langsung variabel minat terhadap pembelajaran kewirausahaan sosial pada mahasiswa.

Hal ini menunjukan pendidikan kewirausahaan pada generasi milineal yang dilakukan pada perguruan tinggi belum mampu menumbuhkan minat mereka dalam berwirausahaan sosial, untuk itu pola pendidikan kewirausahaan di Perguruan Tinggi harus lebih disempurnakan dengan metode pembelajaran yang mudah dipahami mahasiswa. Hasil penelitian ini 
menunjukan hasil yang sejalan dengan penelitian sebelumnya dilakukan (Lanero et al, 200) pada mahasiswa yang telah lulus sarjana di Spanyol. Hasil penelitian menunjukan bahwa pendidikan kewirausahaan masih belum mampu untuk menumbuhkan minat mahasiswa untuk berwirausahaan.

\section{Kemampuan}

melalalui

\section{Pembelajaran Kewirausahaan}

Sosial terhadap Milineal

Entrepreneur

Pembelajaran kewirausahaan sosial pada mahasiswa dalam model penelitian ini memiliki mediasi hubungan antara kemampuan terhadap milineal entrepreneur. Variabel pembelajaran kewirausahaan sosial mengakibatkan variabel kemampuan mempengaruhi variabel milineal entrepreneur secara tidak langsung. Hal ini ditunjukan dari nilai pengaruh tidak langsung variabel kemampuan terhadap milineal entrepreneur lebih besar dari nilai pengaruh langsung variabel kemampuan terhadap milineal entrepreneur.

Dalam satu kelas kemampuan mahasiswa untuk menyerap pembelajaran berbeda-beda, demikian gaya belajarnya. Dengan adanya pembelajaran kewirausahaan sosial dapat memberi motivasi kepada mahasiswa untuk menjadi milineal entrepreneur karena kepada mereka telah diberikan pengetahuan melalui pola pendidikan kewirausahaan.

\section{SIMPULAN}

Derdasarkan hasil analisis dan pembahsana tentang "Menciptakan Milenial Entrepreneur Melalui Pembelajran Kewirausahaan Sosila Pada Mahasiswa" dapat ditarik kesimpulan sebagai berikut :

1. Variabel minat berpengaruh positif dan siqnifikan terhadap pembelajaran kewirausahaan sosial akan tetapi variabel minat tidak berpengaruh terhadap milenial entrepreneur dan Variabel minat melalui pembelajaran kewirausahaan sosial tidak juga berpengaruh signifikan terhadap milenial entrepreneur. 
2. Variabel kemampuan berpengaruh positif dan signifikan terhadap pembelajaran kewirausahaan sosial tetapi variabel variabel Kemampuan tidak berpengaruh terhadap milenial entrepreneur dan variabel kemampuan melalui pembelajaran kewirausahaan sosial berpengaruh signifikan terhadap milenial entrepreneur

\section{Keterbatasan penelitian}

Menjadi sebuah polemik bagi dunia pendidikan ketika harus melakukan pertemuan intens dengan mahasiswa secara langsung. Beruntung zaman ini telah dianugrahi beberapa jenis aplikasi yang membantu pertemuan antara pengajar dan peserata didik secara virtual. Meskipun sudah didukung oleh kecanggihan teknologi, kendala tentu saja tetap ada. Misalnya peneliti dan mahasiswa merasa kewalahan karena praktek dan keleluasaan untuk bergerak diluar sangat terbats, sehingga membuat teori tidak dapat diterapkan secara maksimal. Selain dari itu, ternyata keterbatsan mahsiswa dalam mengakses internet selama pendami covid-19 juga menjadi sebuah kendala, dimana mahasiswa kesulitan menggunakan aplikasi berbasiss interet karena kebanyakan di antara mereka sedang pulang ke kampungnya masing-masing dengan kondisi jaringan internet yang sangat buruk. Begitupun dengan pengawasan terhadap kegiatan yang dilakukan oleh mahasiswa tidak dapat dilakukan secara optimal dikarenakan ruang gerak yang sangat terbatas.

\section{DAFTAR PUSTAKA}

Aprilianty, E. 2012. Pengaruh Kepribadian Wirausaha, Pengetahuan Kewirausahaan, dan Lingkungan terhadap Minat Berwirausaha Siswa SMK. Jurnal Pendidikan Vokasi. Vol. 2, No. 3, 311-324 Ajzen, Icek. 2005. Attitudes, Personalitiy, and Behavior. Edisi Kedua. New York: Open University Press.

Hockerts, K., \& Wustenhagen, R. 2010. Greening Goliaths Versus Emerging Davids: Theorizing abaut The Role of Incumbents and New Entransts in

Sustainable 
Enterpreneurship. Journal of Business Venturing, 25(5), 481-492

Ibrahim, Amin. 2008. Teori dan Konsep Pelayanan Publik Implementasinya. Bandung: Mandar Maju

Miraza, Bachtiar Hassan. 2008. Mencermati Pelaku Entrepreneur. Penerbit USU. Press Medan

Mukhmad, Zulianto dkk, 2014. Pengaruh Efikasi Diri dan Pendidikan Kewirausahaan terhadap Minat Berwirausahaan Mahasiswa Pendidikan Tata Niaga Fakultas Ekonomi Universitas Negeri Medan 2013. Jurnal pendidikan Insan mandiri: Vol.3 No.1 Dipetik 06 20, 2017 dari http://jurnal.fkip.uns.ac.id/inde x.php/s2ekonomi/articel/view/6 $\underline{817}$

Nichollas, Alex, 2006. Social Entrepreneurship: New Models of Sustainable Social Change. New York: Oxford University Press

Robbins, Stephen P. \& Timothy A. Judgo. 2008. Prilaku Organisasi. Jakarta. Salemba Empat

Robbins SP, dan Judge. 2008. Perilaku Organisasi Buku 2. Jakarta : Salemba Empat

Winardi, 2003, Entrepreneur dan Entrepreneurship, Cetakan Kedua, CV.Kencana: Jakarta. https://www.kominfo.go.id/content/d etail/8566/mengenal-generasimillennial/0/sorotan media https://www.dbs.com/iwovresources/pdf/indonesia/socialgood/Berani\%20jadi\%20SEPORTRAIT\%2030\%20Mar\%202016low.pdf

file:///C:/Users/WIN\%207/Downloads/2618 1-54555-1-PB.pdf

file://C:/Users/WIN\%207/Downloads/318Article\%20Text-2337-3-1020180821.pdf 